\title{
Fruit maturation stage on the physiological quality of maroon cucumber seeds ${ }^{1}$
}

\author{
Cleisson Dener da Silva², Andréia Márcia Santos de Souza David², \\ Josiane Cantuária Figueiredo ${ }^{2}$, Jorge Luiz Rodrigues Barbosa ${ }^{2}$, Rayane Aguiar Alves ${ }^{2}$
}

To obtain seeds of high physiological quality, it is of paramount importance to define the ideal harvest moment, which oftentimes corresponds to the period when the physiological maturity is reached. This experiment aimed to study the maturation process and determine the best harvest season of maroon cucumber fruits (Liso Gibão cultivar), in order to reach the maximum physiological seed quality. The flowers were labeled during the anthesis and the fruits harvested at 14, 21, $28,35,42,49$ and 56 days after the anthesis (DAA). The fruits had their visual aspects registered by photography analysis and, later, the seeds were extracted for physical (water and dry matter contents) and physiological (germination, seedling emergence, emergence speed index, accelerated aging and electrical conductivity) analyses. It was observed that the seeds reach the maximum dry mass $\left(8.08 \mathrm{mg} \mathrm{seed}^{-1}\right)$ between 47 and 49 DAA. However, the seed physiological maturity, characterized by a maximum germination (70 \%) and vigor, occurs at 56 DDA. The best season to harvest seeds with a higher physiological quality takes place from 49 to $56 \mathrm{DDA}$, when the fruits present a yellowish color.

KEYWORDS: Cucumis anguria L., germination, seed maturity.

\section{INTRODUCTION}

Maroon cucumber (Cucumis anguria L.) is a vegetable that belongs to the Cucurbitaceae family, widely grown in the northern and northeastern regions of Brazil (Oliveira et al. 2017), being produced in a nonconventional way and commercialized in food supply networks, grocery stores and street markets. Produced to a lesser extent in the Brazilian center-southern region, it stands out as a popular delicacy in the north of the Minas Gerais state (Modolo \& Costa 2003).

\section{RESUMO}

Estádio de maturação do fruto na qualidade fisiológica de sementes de maxixe

Para a obtenção de sementes de alta qualidade fisiológica, é imprescindível a definição do momento ideal de colheita, o qual corresponde, frequentemente, à época em que a maturidade fisiológica é atingida. Objetivou-se avaliar o processo de maturação e determinar a melhor época de colheita de frutos de maxixe (cultivar Liso Gibão), visando à máxima qualidade fisiológica das sementes. As flores foram etiquetadas durante a antese e os frutos colhidos aos 14, 21, 28, 35, 42, 49 e 56 dias após a antese (DAA). Os frutos tiveram os seus aspectos visuais registrados por meio de fotografias e, posteriormente, as sementes foram extraídas para a realização de análises físicas (teor de água e matéria seca) e fisiológicas (germinação, emergência de plântulas, índice de velocidade de emergência, envelhecimento acelerado e condutividade elétrica). Verificou-se que as sementes atingem o máximo de massa seca $\left(8,08 \mathrm{mg} \mathrm{semente}^{-1}\right)$ entre 47 e 49 DAA. No entanto, a maturidade fisiológica das sementes, caracterizada pelo máximo de germinação (70 \%) e vigor, ocorre aos 56 DAA. A melhor época para realizar a colheita das sementes com maior qualidade fisiológica ocorre de 49 a 56 DAA, quando os frutos apresentam coloração amarelada.

PALAVRAS-CHAVE: Cucumis anguria L., germinação, maturidade de sementes.

It is mainly consumed as maxixada, obtained from cooking its ripe fruits along with other ingredients; in natura, as salad; and potted, as pickles. It is a rich source of mineral salts (zinc, calcium, iron, phosphorus, magnesium and sodium), as well as vitamin $\mathrm{C}$ and $\mathrm{B}$-complex vitamins, in addition to being considered a highly-energetic food (Taco 2011).

It is mainly grown by small farmers and, due to the fact that the producers do not manage the crops properly and do not have knowledge about the precise 
season for harvest, the physiological quality of the produced seeds is low (Medeiros et al. 2010).

The first step to obtain seeds with high physiological quality is to determine the ideal harvest season, which frequently corresponds to the season when physiological maturity is reached, coinciding with the moment of maximum dry matter accumulation, high vigor and high germination potential (Carvalho \& Nakagawa 2012).

However, the maturation process of this species is uneven, for presenting an undetermined growth habit (Modolo \& Costa 2003), in which flowering and fruiting occur continuously, with seeds and fruits being found at different maturation stages in the same plant (Marcos-Filho 2015). Thus, flowering and seed production happen during a longer time interval, revealing the influence of maturation on the physiological quality of seeds.

During the physiological maturation of seeds, there are changes in the external aspect and color of fruits, serving as parameters for the physiological maturity identification. However, the uneven color of maroon cucumber fruits throughout their cycle has been hindering the definition of the precise seed maturation moment.

The physiological maturation of vegetables has been determined by means of several characterizations, such as number of days from anthesis to fruit maturation, dry matter mass stabilization and water content of seeds (Nascimento 2009).

Thus, the present investigation aimed to study the maturation process and determine the best harvest season of maroon cucumber fruits for reaching the maximum seed physiological quality.

\section{MATERIAL AND METHODS}

The seed production field was installed at the experimental area of the Universidade Estadual de Montes Claros, in Janaúba, Minas Gerais state, Brazil, where the climate, according to the Köppen classification, is Aw (rainy tropical with a dry winter). Monthly climatic data during the conduction of the experiment are displayed in Figure 1.

The Liso Gibão cultivar was used, and the treatments were seven harvest seasons $(14,21,28,35$, 42, 49 and 56 days after the anthesis - DAA), under a completely randomized experimental design, in an area of $84 \mathrm{~m}^{2}(12 \mathrm{~m} \times 7 \mathrm{~m})$. The flowers were labeled daily, with 30 markings being made at different days during the anthesis (seven-day period), and, in each harvest season, 20 fruits were randomly collected.

The soil preparation for the experiment implantation consisted of cleaning the area, followed by opening pits with a spacing of $1 \mathrm{~m}$ between lines and $1 \mathrm{~m}$ between plants, with the aid of a hoe. Fertilization was based on the soil chemical characteristics ( $0-20 \mathrm{~cm}$ of depth), by incorporating $30 \mathrm{t} \mathrm{ha}^{-1}$ of tanned cattle manure, in addition to a total application of $60 \mathrm{~kg} \mathrm{ha}^{-1}$ of $\mathrm{P}_{2} \mathrm{O}_{5}, 120 \mathrm{~kg} \mathrm{ha}^{-1}$ of $\mathrm{K}_{2} \mathrm{O}$ and $120 \mathrm{~kg} \mathrm{ha}^{-1}$ of $\mathrm{N}$, in the form of simple superphosphate, potassium chloride and urea, respectively (Ribeiro et al. 1999).

The seeds were sown in May 2017 (three seeds per pit) and, at 15 days after planting, thinning was performed, resulting in only one plant left. After sowing, technical recommendations necessary for the proper development of the crop were adopted, including drip-system irrigation, pest monitoring and manual weed control.

After harvest, the seeds were extracted manually and homogenized to compose the sample. From this sample, four subsamples of 100 seeds were collected to determine the water content by the oven method at $105 \pm 3{ }^{\circ} \mathrm{C}$, for $24 \mathrm{~h}$, with results being expressed as percentage (Brasil 2009). Simultaneously, the dry matter mass of the seeds was determined, with results expressed as $\mathrm{mg} \mathrm{seed}^{-1}$.

The other seeds were immersed for $2 \mathrm{~min}$ in a sodium hypochlorite solution at $2.0 \%$ and washed in running water for $2 \mathrm{~min}$. Afterwards, they were

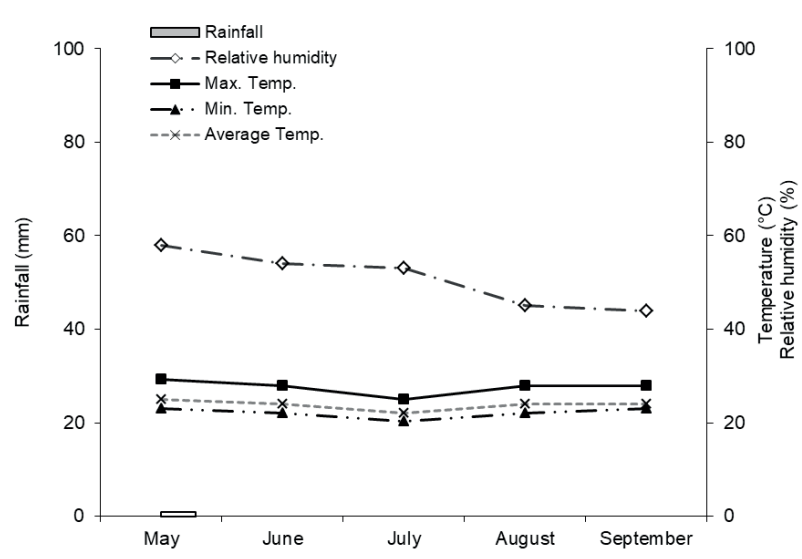

Figure 1. Monthly climatic data on total rainfall; maximum, minimum and average temperatures; and relative air humidity registered during the conduction of the experiment, in 2017. 
left drying on paper towel under ambient laboratory conditions $\left( \pm 26^{\circ} \mathrm{C}\right)$, for $48 \mathrm{~h}$. Then, the other analyses were run for assessing the seeds physiological quality.

For the germination test, four subsamples of 50 seeds were sown on germitest paper towels moistened with distilled water, in a volume equivalent to 2.5 times the dry weight, and then arranged in gerbox-type plastic boxes. The boxes containing the seeds were left inside digital germinators regulated at alternating temperatures of $20-30^{\circ} \mathrm{C}$ and photoperiod of $8 \mathrm{~h}$, with assessments being carried out on the 4 th and 8th days after sowing and results expressed as percentage of normal seedlings (Brasil 2009).

The seedling emergence test was conducted under ambient laboratory conditions $\left( \pm 26^{\circ} \mathrm{C}\right)$, using washed and sterilized sand as substrate. The seeds were sown at a depth of $0.5 \mathrm{~cm}$, in gerbox-type plastic boxes containing the substrate moistened with an amount of water equivalent to $50 \%$ of the retention capacity (Brasil 2009), whose moisture was maintained by means of daily irrigation. Four subsamples of 50 seeds were used and results were expressed as percentage of emerged normal seedlings, adopting as assessment criterion seedlings emerged above the substrate with expanded cotyledon leaves.

The emergence speed index was analyzed together with the seedling emergence test, with daily recording of the number of seedlings that had visible strap-like leaves above the substrate surface up to the 8th day after sowing. At the end of the test, the emergence speed index was calculated by employing the formula proposed by Maguire (1962).

The accelerated aging test used a single layer of 400 seeds distributed evenly on a net attached to the gerbox-type plastic boxes containing $40 \mathrm{~mL}$ of distilled water. The boxes were capped and left in a BOD chamber at $41^{\circ} \mathrm{C}$, for $72 \mathrm{~h}$ (Torres \& MarcosFilho 2001). Then, 200 seeds were subjected to the germination test, as previously described, counting four days after sowing.

The electrical conductivity test was performed by the mass method, using four subsamples of 50 physically-pure seeds for each treatment. The seeds were weighed on a precision analytical scale (0.01). Subsequently, they were put inside plastic cups containing $75 \mathrm{~mL}$ of distilled water and subjected to a constant temperature of $25^{\circ} \mathrm{C}$, for $24 \mathrm{~h}$ of incubation. Afterwards, the electrical conductivity of the solution was read on a digital conductivity meter and results expressed as $\mu \mathrm{S} \mathrm{cm}^{-1} \mathrm{~g}^{-1}$ of seeds, with this methodology being adopted for the analysis of agricultural seeds, as recommended by Vieira \& Krzyzanowski (1999).

As the experiment was conducted, the accumulation of thermal units was determined in degree-days, being this one of the main methods that relates the development rate of a plant species to the temperature of the medium. The degree-days calculation was done according to Villa Nova et al. (1972), employing the base temperature of $12{ }^{\circ} \mathrm{C}$ proposed by Baker \& Reddy (2001) for melon crops and Heldwein \& Andriolo (1988) for cucumber crops.

Data were tested according to assumptions of normality and homogeneity of variances. Because these two assumptions were met, the results from the physical and physiological quality assessments on the seeds were subjected to analysis of variance and regression at $5 \%$ of probability, by the F test. Estimates of regression parameters were assessed by the $t$ test at $5 \%$ of significance.

\section{RESULTS AND DISCUSSION}

The color of the fruits varied according to the harvest season (Figure 2). At the 14th day after the anthesis (DAA), the fruits were unripe and had a dark green color. In those fruits harvested at 21, 28 and 35 DAA, there were changes in color, from dark to light green. With the chlorophyll degradation, a pigment responsible for the green color of fruits and vegetables and for the accumulation of other pigments such as carotenoids and anthocyanins (Taiz \& Zeiger 2009), the color of the fruits changed completely, with a yellowish epicarp at 42, 49 and 56 DAA.

One of the main parameters used in the field to identify the physiological maturity of seeds, as well as the ideal harvest point, has been the fruit age and color (Justino et al. 2015). In species such as maroon cucumber, with fleshy fruits, the physiological maturity happens as the color of the epicarp changes.

The results for seed water content fit into a regression equation of linear ascending behavior $(p<$ 0.05 ), with reductions in values being proportional to the harvest seasons (Figure 3A).

The seed water content, which initially was $84.7 \%$ (14th DAA), decreased sharply until reaching $38.2 \%$ (56th DAA - last harvest), accounting for a $54.9 \%$ reduction, in relation to the initial water content. The high water content in the seeds harvested 
at the 14th DAA can be explained by the need for both the translocation of metabolites from plant to seeds and cell expansion (Bewley et al. 2013). Moreover, it can also be associated with the need to synthetize and metabolize reserve substances that occur in aqueous medium by seeds (Marrocos et al. 2011), with these reserves being represented by proteins, sugars, lipids and carbohydrates.

At the 56th DDA, when the last harvest happened, the seeds reached a high water content $(38.2 \%)$. For being a fleshy fruit, the seeds, upon reaching the physiological maturity, keep their water content high (Marcos-Filho 2015), because the dehydration process in seeds of fleshy fruits is slow, and, after reaching the physiological maturity, orthodox seeds, such as those of maroon cucumber, have a water content within the range of 30-50\% (Carvalho \& Nakagawa 2012). In this case, the seeds normally do not go through a phase of rapid dehydration neither through great oscillations in their water content, since they are protected inside a fleshy, water-rich fruit, as a consequence of the relative humidity inside the fruit (Demir et al. 2002).

Medeiros et al. (2010) found that maroon cucumber seeds (Do Norte cultivar) presented a water

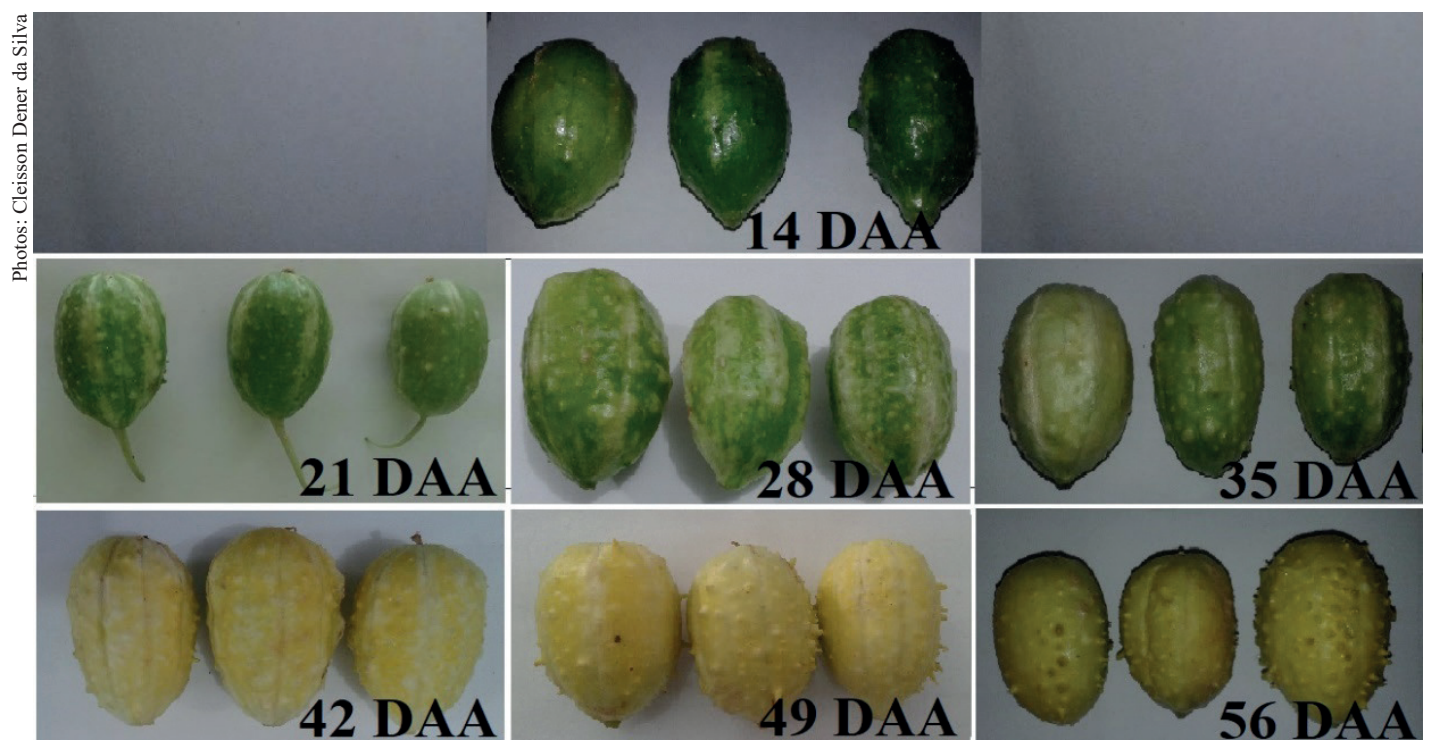

Figure 2. Visual aspect of maroon cucumber fruits (Liso Gibão cultivar) harvested at 14, 21, 28, 35, 42,49 and 56 days after the anthesis (DAA).

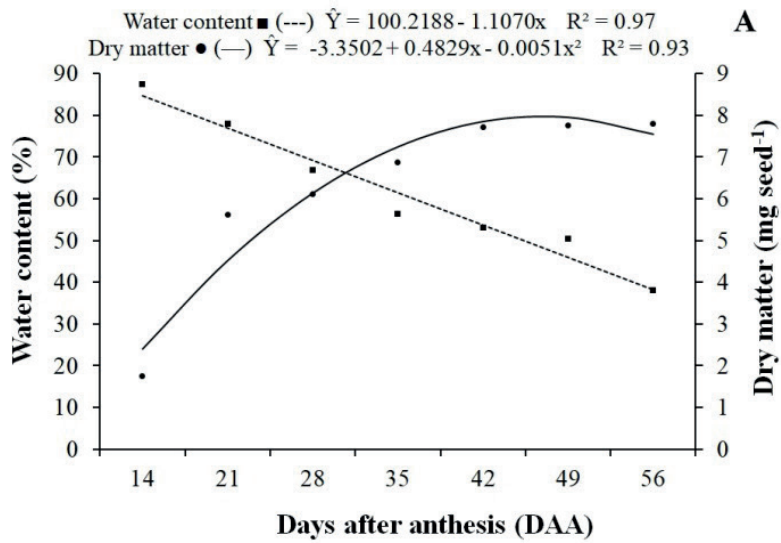

A

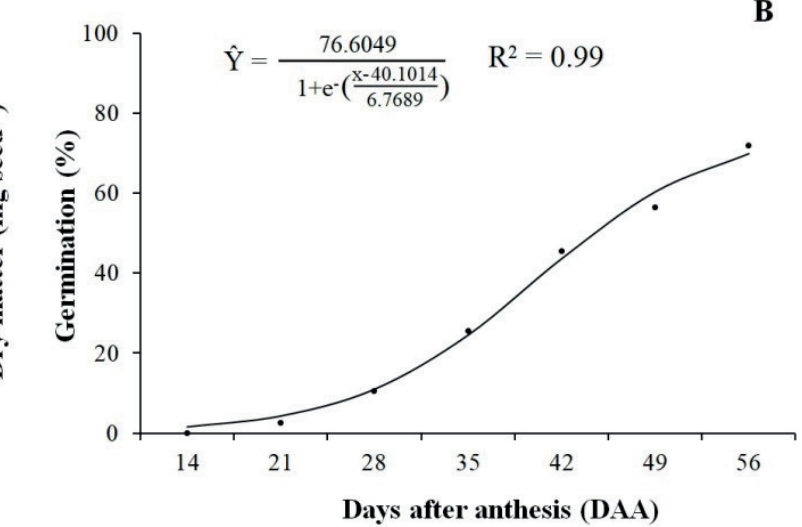

Figure 3. Water and dry matter content (A) and germination (B) of maroon cucumber seeds (Liso Gibão cultivar), according to days after the anthesis (harvest seasons). 
content of $50.6 \%$ at the 40 th DDA, a result that is similar to that observed in the present study $(55.9 \%)$.

It should be noted that, though widely used, the seed water content cannot be considered the most adequate indicator of physiological maturity, since it can be affected by genotype and ambient conditions (Vidigal et al. 2011). However, the knowledge on changes in the seed water content is of vital importance when studying the maturation process.

The results for seed dry matter accumulation adjusted to a quadratic model $(\mathrm{p}<0.05)$ (Figure 3A). The seed dry matter mass, which, at the 14th DAA was $2.41 \mathrm{mg} \mathrm{seed}^{-1}$, increased sharply until reaching the maximum weight of $8.08 \mathrm{mg} \mathrm{seed}^{-1}$ at the $47 \mathrm{th}$ DAA, defining this as the point of mass maturation (Ellis \& Pieta Filho 1992). These values show an increase of $235.3 \%$ in the seed dry matter in the first harvest season until the maximum point, which represented a thermal sum of 1,379.70 degree-days. At this seed development stage, the fruits presented an intense yellow color (Figure 2). After the seeds reach a maximum dry matter content, they no longer receive photoassimilates, and detach from the mother-plant (Figueiredo et al. 2017).

Medeiros et al. (2010), after studying the physiological maturation of maroon cucumber seeds (Do Norte cultivar) produced in Mossoró, Rio Grande do Norte state, Brazil, verified that the seeds reached a maximum dry matter accumulation at 40 DAA, against the 47 DAA found in the present experiment.

At the 49th DAA, there was a small decrease in the seed dry matter, reaching $7.70 \mathrm{mg} \mathrm{seed}^{-1}$, possibly as a result of losses for the seed respiration, after reaching the point of mass maturity. In this sense, Carvalho \& Nakagawa (2012) reported that the dry mater is maintained for a while, and may have a small reduction at the end of the maturation period, due to the consumption of reserves caused by the seed respiration.

The seed germination percentage increased as the fruit maturation advanced (Figure 3B), resulting in a sigmoidal behavior $(\mathrm{p}<0.05)$. At the 14 th DAA, the seed germination was inexpressive (2\%). At this development stage, not all seeds have their embryos completely formed, thus being immature to germinate. Besides, at this maturation stage, the seeds presented a high water content $(84.7 \%)$, what means that the seeds might still be accumulating the reserves necessary for the germination process (Carvalho \& Nakagawa 2012).
At the 14th DAA, the seed germination percentage increased gradually, with the maximum value $(70 \%)$ being observed at the 56th DAA, which coincided with the lowest seed water content (38.2\%) and with the maximum dry matter accumulation, representing a thermal sum of 1,423.05 degree-days. It is important to highlight that the germination at the 56th DAA falls within the standards for the commercialization of maroon cucumber seeds, which meet the minimum percentage required for basic seeds: $70 \%$ (Brasil 2012).

Marrocos et al. (2011), studying the maturation of zucchini seeds (Menina Brasileira cultivar), verified that the germination percentage increases throughout harvests, with some stability being observed between the 40th and 50th DAA, this period being considered as a possible indication of seed maturity, reaching the maximum of $86 \%$ at the 60 th DAA. Costa et al. (2002), in turn, verified a maximum germination potential for hybrid-zucchini seeds from the 60th to the 70th DAA.

Several studies (Lopes et al. 2005, Pereira et al. 2014, Justino et al. 2015) evidence that the maximum dry matter accumulation, maximum germination capacity and vigor characterize the period when the seed reaches its physiological maturity. However, the season when the maximum dry matter accumulation occurs does not always coincide with the period of maximum germination, as it happened in this study.

The seedling emergence presented a sigmoidal behavior $(p<0.05)$ throughout the harvest seasons and seeds from fruits harvested at early maturation stages showed lower emergence percentages, which increased as harvests advanced (Figure 4A). The worst performances were observed in seeds extracted from unripe fruits (14 DAA), with virtually null emergence $(1 \%)$. The maximum value $(66 \%)$ was obtained from seeds of fruits harvested at the 56th DAA.

Sanches et al. (2017) observed that the emergence percentage of seedlings from Italian zucchini seeds, harvested at the 25th DAA, was lower, in relation to those harvested at the 50th DAA, with $14 \%$ and $54 \%$, respectively.

The results for emergence speed index adjusted to a sigmoidal behavior model $(\mathrm{p}<0.05)$. At 14 and 21 DAA, the seeds showed null indexes (Figure 4B), what can be attributed to the embryo immaturity, as already reported. The values increased as the harvest season of the fruits advanced. 

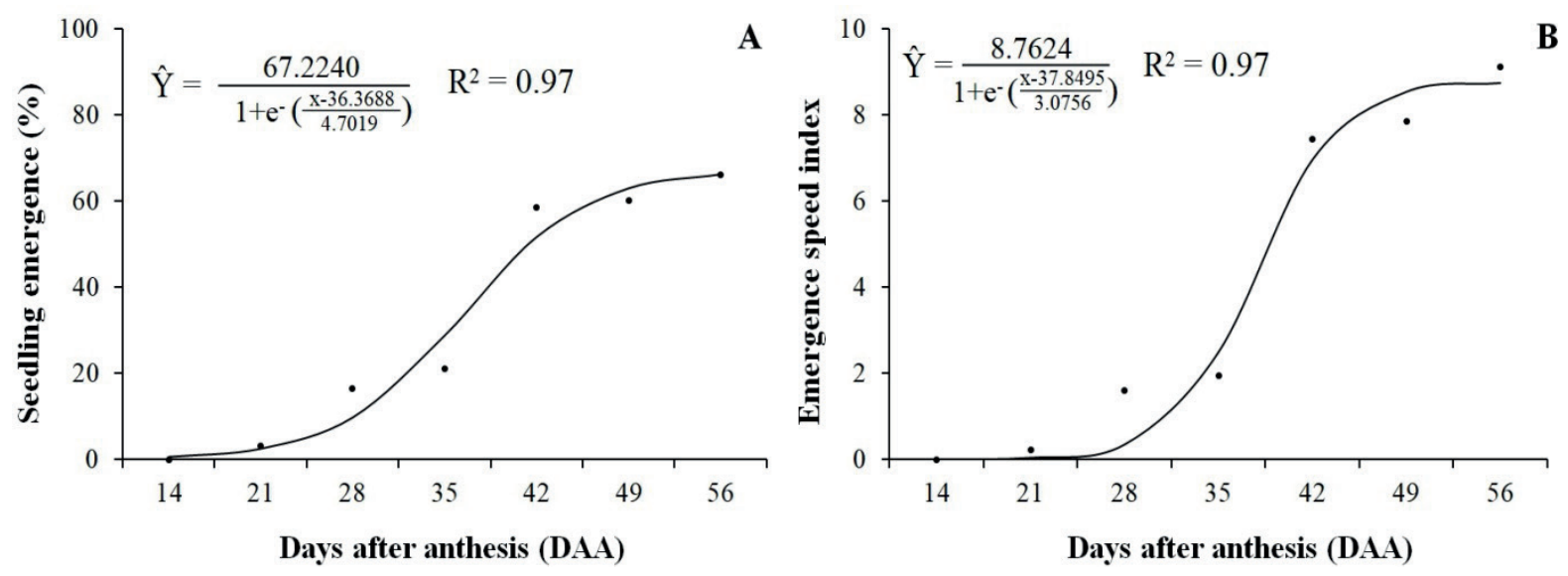

Figure 4. Emergence (A) and emergence speed index (B) of seedlings from maroon cucumber seeds (Liso Gibão cultivar), according to days after the anthesis (harvest seasons).

The highest emergence speed index value (8.74) was found in seeds from fruits harvested at 56 DAA. Higher indexes indicate that the seedlings emerged more rapidly and evenly, being related to the seed physiological maturity and to the accumulation of reserves, indicating the fruit complete maturation.

Marrocos et al. (2011), studying the maturation of zucchini seeds (Menina Brasileira cultivar), verified a null emergence speed index at the 20th DAA, with increases up to the 60th DAA, when it reached an index of 13.8 .

The accelerated aging presented a sigmoidal behavior $(p<0.05)$ throughout the harvest seasons (Figure 5A). Initially, at the 14th DAA, the seed vigor was null, raising progressively as a function of the maturation stage, with the maximum vigor $(68 \%)$ being reached at 56 DAA, coinciding with the results found for germination (Figure 3B), seedling emergence (Figure 4A) and emergence speed index (Figure 4B). This evidences that, in that period, the seeds are completely formed, due to the high germination percentage, after being subjected to stress conditions during the accelerated aging.

Presenting a potential behavior $(p<0.05)$, the results for seed electrical conductivity reduced as the harvest seasons advanced, indicating an increase in seed vigor (Figure 5B). Seeds from fruits harvested at 14 DAA presented superior values $\left(1.248,46 \mu \mathrm{S} \mathrm{cm}^{-1} \mathrm{~g}^{-1}\right)$. Most likely, in this harvest season, the seeds were more immature, suggesting a disorganization of the cell membrane, which favored a greater leaching of solutes (Alves 2016).

The lowest value was found in seeds from fruits harvested at $56 \mathrm{DAA}$, being equivalent to $32.29 \mu \mathrm{S} \mathrm{cm}^{-1} \mathrm{~g}^{-1}$. This reduction in the seed electrical
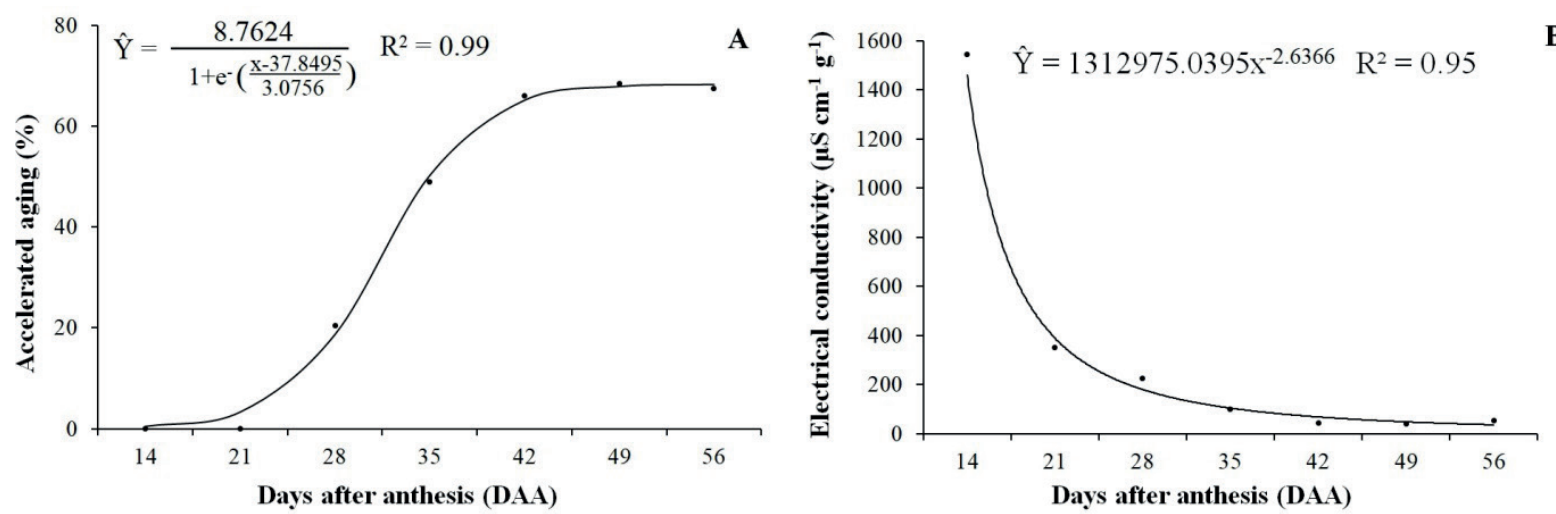

Figure 5. Accelerated aging (A) and electrical conductivity (B) of maroon cucumber seeds (Liso Gibão cultivar), according to days after the anthesis (harvest seasons). 
conductivity values may be due to the adequate structuration of the cell membranes, restricting the leaching of solutes as the point of physiological maturation approaches.

There is a possibility that the cell membrane protection system be inefficient at early development stages, when the membranes are not properly formed yet (Martins et al. 2012). Thus, membrane deterioration processes start at earlier development stages, when the membranes are poorly structured.

\section{CONCLUSIONS}

1. Maroon cucumber seeds (Liso Gibão cultivar) reach a maximum dry matter between 47 and 49 days after the anthesis;

2. The seed physiological maturation (maximum germination and vigor) occurs at the 56th day after the anthesis;

3. The best season to harvest maroon cucumber seeds with a higher physiological quality is 49 and 56 days after the anthesis, when the fruits present a yellowish color.

\section{REFERENCES}

ALVES, M. V. P. Caracterização física e fisiológica de sementes de jiló (Solanum gilo) em diferentes estádios de desenvolvimento. Tese (Doutorado em Fitotecnia) Universidade Federal de Lavras, Lavras, 2016.

BAKER, J. T.; REDDY, V. R. Temperature effects on phenological development and yield of muskmelon. Annals of Botany, v. 87, n. 5, p. 605-613, 2001.

BEWLEY, J. D. et al. Seeds: physiology of development, germination and dormancy. New York: Springer, 2013.

BRASIL. Ministério da Agricultura, Pecuária e Abastecimento. Padrões de identidade e qualidade para a produção e a comercialização de sementes de espécies olerícolas, condimentares, medicinais e aromáticas. Portaria no 111, de 04 de setembro de 2012. Diário Oficial da União, Brasília, DF, 05 set. 2012. Seção 1, p. 3.

BRASIL. Ministério da Agricultura, Pecuária e Abastecimento. Regras para análise de sementes. Brasília, DF: MAPA/ACS, 2009.

CARVALHO, N. M.; NAKAGAWA, J. Sementes: ciência, tecnologia e produção. 5. ed. Jaboticabal: Funep, 2012.

COSTA, C. J. et al. Efeito da idade e do armazenamento dos frutos na qualidade fisiológica de sementes híbridas de abóbora. Horticultura Brasileira, v. 20, n. 2, p. 1-4, 2002.
DEMIR, I. et al. Seed development and maturation in aubergine (Solanum melongena L.). Gartenbauwissenschaft, v. 67, n. 4 , p. $148-154,2002$.

ELLIS, R. H.; PIETA FILHO, C. Seed development and cereal seed longevity. Seed Science Research, v. 2, n. 1, p. 9-15, 1992.

FIGUEIREDO, J. C. et al. Maturação de sementes de pimenta em função de épocas de colheita dos frutos. Revista Scientia Agraria, v. 18, n. 3, p. 1-7, 2017.

HELDWEIN, A. B.; ANDRIOLO, J. L. Temperatura base e soma térmica do subperíodo de floração-maturação do pepino. In: HELDWEIN, A. B.; ANDRIOLO, J. L. (Eds.). Encontro de hortaliças da região sul. Santa Maria: UFSM, 1988. p. 1-68.

JUSTINO, E. V. et al. Determinação da maturidade fisiológica de sementes de pimenta dedo de moça Capsicum baccatum var. pendulum. Horticultura Brasileira, v. 33, n. 3, p. 324-331, 2015.

LOPES, J. C. et al. Maturação fisiológica de sementes de quaresmeira. Pesquisa Agropecuária Brasileira, v. 40, n. 8, p. 811-816, 2005.

MAGUIRE, J. D. Speed of germination-aid in selection and evaluation for seedling emergence and vigor. Crop Science, v. 2, n. 2, p. 176-177, 1962.

MARCOS-FILHO, J. Fisiologia de sementes de plantas cultivadas. 2. ed. Londrina: Abrates, 2015.

MARROCOS, S. T. P. et al. Maturação de sementes de abobrinha menina brasileira. Revista Brasileira de Sementes, v. 33, n. 2, p. 272-278, 2011.

MARTINS, D. C. et al. Physiological maturity of eggplant seeds. Revista Brasileira de Sementes, v. 34, n. 4, p. 534540, 2012.

MEDEIROS, M. A. et al. Maturação fisiológica de sementes de maxixe (Cucumis anguria L.). Revista Brasileira de Sementes, v. 32, n. 3, p. 17-24, 2010.

MODOLO, V. A.; COSTA, C. P. Maxixe: uma hortaliça de tripla forma de consumo. Piracicaba: DIBD/ESALQ, 2003. (Boletim técnico, 19).

NASCIMENTO, W. M. Tecnologia de sementes de hortaliças. Brasília, DF: Embrapa Hortaliças, 2009.

OLIVEIRA, F. A. et al. Substrato e bioestimulante na produção de mudas de maxixeiro. Horticultura Brasileira, v. 35, n. 1, p. 141-146, 2017.

PEREIRA, F. E. C. B. et al. Qualidade fisiológica de sementes de pimenta em função da idade e do tempo de repouso pós-colheita dos frutos. Revista Ciência Agronômica, v. 45, n. 4, p. 737-744, 2014. 
RIBEIRO, A. C.; GUIMARÃES, P. T. G.; ALVAREZ, V. H. Recomendações para uso de corretivos e fertilizantes em Minas Gerais: $5^{\text {a }}$ aproximação. Viçosa: Comissão de Fertilidade do Solo do Estado de Minas Gerais, 1999.

SANCHES, A. G. et al. Índice de maturação fisiológica em sementes do híbrido de abobrinha italiana em função da idade de colheita. Revista Trópica: Ciências Agrárias e Biológicas, v. 9, n. 1, p. 41-49, 2017.

TABELA BRASILEIRA DE COMPOSIÇÃO DE ALIMENTOS (Taco). 4. ed. Campinas: Unicamp, 2011.

TAIZ, L.; ZEIGER, E. Fisiologia vegetal. 4. ed. Porto Alegre: Artmed, 2009.

TORRES, S. B.; MARCOS-FILHO, J. Teste de envelhecimento acelerado em sementes de maxixe
(Cucumis anguria L.). Revista Brasileira de Sementes, v. 23, n. 2, p. 108-112, 2001.

VIDIGAL, D. S. et al. Changes in seed quality during fruit maturation of sweet pepper. Scientia Agricola, v. 68, n. 5 , p. 535-539, 2011.

VIEIRA, R. D.; KRZYZANOWSKI, F. C. Teste de condutividade elétrica. In: KRZYZANOWSKI, F. C.; VIEIRA, R. D.; FRANÇA NETO, J. B. (Eds.). Vigor de sementes: conceitos e testes. Londrina: Abrates, 1999. p. 1-26.

VILLA NOVA, N. A. et al. Estimativa de graus-dia acumulados acima de qualquer temperatura-base em função das temperaturas máxima e mínima. Caderno de Ciências da Terra, v. 30, n. 1, p. 1-7, 1972. 